\title{
Downscaling the Gap: Protected Areas, Scientific Knowledge and the Conservation of Amphibian Species in Minas Gerais, Southeastern Brazil
}

\author{
Author(s): Izabela M. Barata, Vivian M. Uhlig, Graziele H. Silva, Guilherme B. Ferreira \\ Source: South American Journal of Herpetology, 11(1):34-45. \\ Published By: Brazilian Society of Herpetology \\ DOI: http://dx.doi.org/10.2994/SAJH-D-16-00006.1 \\ URL: http://www.bioone.org/doi/full/10.2994/SAJH-D-16-00006.1
}

BioOne (www.bioone.org) is a nonprofit, online aggregation of core research in the biological, ecological, and environmental sciences. BioOne provides a sustainable online platform for over 170 journals and books published by nonprofit societies, associations, museums, institutions, and presses.

Your use of this PDF, the BioOne Web site, and all posted and associated content indicates your acceptance of BioOne's Terms of Use, available at www.bioone.org/page/terms_of_use.

Usage of BioOne content is strictly limited to personal, educational, and non-commercial use. Commercial inquiries or rights and permissions requests should be directed to the individual publisher as copyright holder. 


\title{
Downscaling the Gap: Protected Areas, Scientific Knowledge and the Conservation of Amphibian Species in Minas Gerais, Southeastern Brazil
}

\author{
Izabela M. Barata, ${ }^{1,2}$, Vivian M. Uhlig', Graziele H. Silva ${ }^{2}$, Guilherme B. Ferreira ${ }^{2,4,5}$
}

\author{
${ }^{1}$ Durrell Institute of Conservation and Ecology, School of Anthropology and Conservation, University of Kent, Marlowe Building, \\ Canterbury, Kent, CT2 7NR, United Kingdom. \\ 2 Instituto Biotrópicos, Praça JK, 25, Centro, Diamantina, Minas Gerais, Brazil. \\ 3 Centro Nacional de Pesquisa e Conservação de Répteis e Anfíbios, Instituto Chico Mendes de Conservação da Biodiversidade, Rua 229, 95, \\ Setor Leste Universitário, Goiânia, Goiás, Brazil. \\ ${ }^{4}$ Centre for Biodiversity \& Environment Research, University College London, Gower Street, London, WC1E 6BT, United Kingdom. \\ Institute of Zoology, Zoological Society of London, Regent's Park, London, NW1 4RY, United Kingdom. \\ * Corresponding author. Email: ib208@kent.ac.uk
}

\begin{abstract}
Protected areas (PAs) cover a small proportion of the Earth's surface and most species are not covered by the current network. Amphibians are the least represented group in PAs around the world and expanding the network is still the major recommendation for species conservation. We evaluated the effectiveness of PAs in safeguarding endemic amphibians in the Cerrado biome of Minas Gerais state, southeastern Brazil. We conducted a gap analysis to highlight site-based conservation actions for target species within study site. We extracted occurrence points from the national database and calculated the intersection between the minimum convex polygon and natural vegetation remnants for each species. For each target species, we calculated the percentage of the range covered by PAs and assessed the scientific knowledge based on academic publications between 1950-2015. We recorded 206 amphibians in Minas Gerais, of which 127 occur in the Cerrado. We identified 24 target species and concluded that $80 \%$ are insufficiently protected by the current PA network. A quarter of the species have zero coverage and most species have $<30 \%$ of their range legally protected. In southwestern Minas Gerais, we recommend habitat restoration and connectivity to provide additional habitat to target species. In western Minas Gerais, the creation of PA seems to be the best solution. The distribution of target species is concentrated in the Espinhaço Mountain Range, where we recommend the establishment of biodiversity corridors. We examined 246 publications, most of which focus on taxonomy. Few species have sufficient information to have their conservation status re-assessed, with only $26.8 \%$ of publications containing specific information on conservation. Scientific knowledge must be improved for all research areas, especially species distributions and ecology, to support evidence-based conservation and management actions.
\end{abstract}

Keywords. Cerrado; DD species; Endemic species; Geographical information system; Protected areas effectiveness; Representativeness.

\section{INTRODUCTION}

Although $15.4 \%$ of the Earth's land surface is formally protected (Juffe-Bignoli et al., 2014), the Convention on Biological Diversity (Aichi Biodiversity Target 11 ) advocated an increase in protected area (PA) coverage to at least $17 \%$ by 2020 (CBD, 2015) —an expansion of 2.2 million $\mathrm{km}^{2}$. Despite an increase in the number and coverage of PAs in the last few decades (Watson et al., 2014), 85\% of threatened birds, mammals, and amphibians are still not adequately protected (Venter et al., 2014). Amphibians are the least represented group inside PAs around the world (Rodrigues et al., 2004); a recent estimate identifies $42 \%$ of all amphibian species as not represented in PAs or with less than $5 \%$ of their distribution covered by such areas (Nori et al., 2015). This may be a consequence of biased selection criteria to establish PAs, with emphasis on charismatic megafauna and certain ecosystems, resulting in an unbalanced representation of biodiversity within the network (Beresford et al., 2010; Sritharan and Burgess, 2011).

Amphibians represent the highest proportion of threatened species among all vertebrates $(41 \%$ are threatened; Pereira et al., 2012) and are declining more rapidly than either birds or mammals (Stuart et al., 2004). Populations are declining worldwide due to fungal diseases (Pounds et al., 2006; Lips et al., 2008), use of agrochemicals (Kiesecker, 2002), climate change (Griffiths et al., 2010; Shoo et al., 2011) and habitat loss and fragmentation (Becker et al., 2007). However, knowledge on amphibian population ecology, species distributions and conservation status is lacking, especially in South American countries (Young et al., 2001). In the Brazilian savannathe Cerrado hotspot, where $51.7 \%$ of amphibian species are endemic (Valdujo et al., 2012)—estimates of threats to amphibians have been poorly investigated (Diniz-Filho et al. 2006, 2007). In Minas Gerais, amphibian research has focused on natural history and distribution patterns, with ecological studies beginning in the late 1990's (Nascimento et al., 2009). However, in the Cerrado biome, population declines are still poorly understood (Eterovick et al., 2005).

Amphibians are not only highly threatened, but also have the highest proportion of Data Deficient species (DD; IUCN, 2014). According to Morais et al. (2013), 25\% 
of DD amphibians are recorded in Brazil, which reflects the level of uncertainty about species conservation status-and also the degree to which they are protected. Although Mace et al. (2008) recommended the same degree of protection to DD species, this proposition is usually disregarded (Trindade-Filho et al., 2012) and species classified in this category receive less attention in conservation plans than those assessed as threatened (Brito, 2010; Trindade-Filho et al., 2012; Morais et al., 2013).

Considering that only $3 \%$ of the original area of the Cerrado is strictly protected (MMA/ICMBio, 2014) and the high amphibian diversity within this biome in Minas Gerais state, southeastern Brazil, herein we evaluate the effectiveness of existing PAs in safeguarding amphibian species that are endemic to Minas Gerais and occur in Cerrado. We conduct a gap analysis to pinpoint where increases in PAs are needed and also where it would be considered most feasible, based on the remaining vegetation cover and past priority recommendations for the study area. Furthermore, as DD accounts for a high proportion of evaluated species in the country, we also investigate the scientific knowledge available for DD target species, according to IUCN assessments. We highlight the shortfalls of scientific knowledge and suggest future research areas that might contribute to the conservation status of amphibians in Minas Gerais.

\section{MATERIALS AND METHODS}

We selected target species based on endemism and considered only species with their entire extent of occurrence (sensu IUCN, 2013) restricted to the state of Minas Gerais, southeastern Brazil. We checked species occurrences using the Amphibian Species of the World database (Frost, 2014), which resulted in a broad description of the geographic distribution within the country. Species listed as occurring in Minas Gerais were double checked using the International Union for Conservation of Nature database on species distributions (IUCN, 2014). Based on the Brazilian official database for major biomes (IBGE, 2014) and on the municipality in which a given species occurred, we assigned each species listed in Minas Gerais to one or more of the three biomes in the state: Cerrado, Atlantic Rainforest and Caatinga. We included species from transitional areas in both biomes of occurrence. Our aim was to produce a database of anuran species from Minas Gerais, with detailed information on species distributions and biome of occurrence. From this database, we selected endemic species of Minas Gerais state occurring in the Cerrado biome. These species were assigned to IUCN Red List categories (IUCN, 2014) and recently described species were assigned as not evaluated (NE). Since we did not consider Least Concern (LC) species in analyses, our final targets were defined as threatened, DD and NE species endemic to Minas Gerais and with occurrence in the Cerrado.

\section{Protected area effectiveness}

We extracted the occurrence points for the target species from a recent database (20,000 records) produced by "Centro Nacional de Pesquisa e Conservação de Répteis e Anfíbios - RAN". Using ArcGIS, we calculated a minimum convex polygon (MCP) for each species based on occurrence data. For species with two or less occurrence points, we assigned a buffer of $10 \mathrm{~km}$, merging buffers whenever they overlapped to each other (i.e., when buffer margins touched an adjacent buffer). Since species are not likely to occur in the whole MCP area, species distribution maps can overestimate the true area of occupancy. To avoid overestimation, we considered as the potential area of occurrence only those areas with natural vegetation inside the $\mathrm{MCP}$ (hereafter species range). To obtain this, we overlapped each species $\mathrm{MCP}$ with a natural vegetation remnants layer (IBAMA/PMDBBS, 2011). Even though this does not guarantee that species will be found in all natural remnants, we believe it provides a more realistic estimate of occurrence and therefore a better estimate of the range covered by PAs.

To assess protection effectiveness, we used the percentage of each species range covered by PAs (i.e., proportional area of species range that is legally protected). To calculate this proportion, we overlapped the range of each species (area with natural vegetation inside the $\mathrm{MCP}$ ) with the PA network layer. We only considered strictly protected areas (according to the Brazilian PA system; SNUC, 2000, equivalent to IUCN categories I-IV; Dudley, 2008) within the state of Minas Gerais. Considering the small scale of our study and given the reduced number of occurrence points, we defined protection effectiveness based on the percentage of habitat covered by a PA within a species' range:

- Not protected (NP): zero coverage and/or $<10 \%$ of range protected

- Unsatisfactorily protected (UP): $10-29 \%$ of range protected

- Partially protected (PP): $30-49 \%$ of range protected

- Satisfactorily protected (SP): $50-80 \%$ of range protected

- Protected $(\mathrm{P}):>80 \%$ of range protected

Finally, to contrast the distribution of target species with previously recommended conservation goals, we overlapped NP species ranges, PAs and natural vegetation remnant layers with the national priority areas for biodiversity conservation (PROBIO/MMA, 2007) and state priority areas for herpetofauna conservation (Drummond et al., 2005). To conduct all spatial analyses we converted shapefiles to the same datum and projection system. 


\section{Scientific knowledge}

We investigated the scientific knowledge produced between 1950-2015 for all target species, including DD species as well as threatened species and species that are yet to be evaluated by the IUCN. We used the scientific name and synonyms of each target species as search criteria in Google Scholar and only considered papers published in peer-reviewed journals. To avoid duplicates or unreliable entries, we analyzed the results and eliminated repeated references. We placed each reference into subject categories (not mutually exclusive; i.e. one paper could have multiple citations and/or be placed in more than one category), according to keywords (in parentheses): Conservation (conservation, decline, vulnerab*, threat*, extinct*); Taxonomy (taxonomy, description, morphology, new species); Ecology (ecolog*, vocal*, diet, temporal distribution, spatial distribution, natural history, predation, behavior); Genetics (genetics, cytogenetic, karyotype, phylogen*, chromosom*); and Distribution (distribution, geographic distribution, new record). When analyzing the content of each paper, we checked if the published data and analysis presented specific information about the species (e.g., taxonomic review, population ecology) or general information about a community (e.g., cited as comparing taxa or listed in a community). Using this approach we produced a list of publications from the last 65 years for each target species according to research area and specific content that could contribute to an evaluation of their conservation status or future conservation plans.

\section{RESULTS}

\section{Protected areas effectiveness in the Cerrado of Minas Gerais State}

We obtained records of 206 amphibian species in Minas Gerais, of which 127 occur in the Cerrado, including species occurring either at Cerrado and Caatinga or at Cerrado and Atlantic Rainforest. We recorded 35 species endemic to Minas Gerais and occurring in the Cerrado biome, representing 151 data points that were used in our analyses. Eleven of these species are classified as LC and the remaining species were considered as targets $(n=24$, Table 1): two are Near Threatened (NT), 16 are DD and six are NE. The number of points retrieved differed among species and, as a consequence, the estimated species ranges differed as well, varying from $125.7-31,729.6 \mathrm{~km}^{2}$ (Table 1). According to our classification, approximately $80 \%$ of the target species are either NP or UP by the current network (Fig. 1A; Table 1). Six species have zero coverage, representing $25 \%$ of our targets (Fig. 1B), and more than half $(n=13)$ are classified as UP. The remaining five species (20.8\%) are $\mathrm{PP}(n=2)$, SP $(n=1)$ or $\mathrm{P}(n=2)$ (Fig. $1 \mathrm{~A}-\mathrm{B})$.
The distribution of target species is highly concentrated in the Espinhaço Mountain Range, a transitional area between the borders of Cerrado and Atlantic Rainforest in eastern Minas Gerais state (Fig. 2). This region shelters one SP and one PP species, but also a high number of UP species $(n=11)$ and one NP species, Physalaemus deimaticus. The southwestern part of the state (close to Serra da Canastra National Park and Triângulo Mineiro) is another region with a considerable number of target occurrences, including the three NP species Ischnocnema karst, I. penaxavantinho and Pseudopaludicola facureae (Fig. 2). There are few records in the central-western state and the only two target species recorded in this region have zero PA cover: Bokermannohyla ravida and Proceratophrys carranca (Fig. 2). The occurrence of all NP species overlapped with priority areas for biodiversity conservation (national priorities; PROBIO/MMA, 2007) or herpetofauna conservation (state priorities; Drummond et al., 2005; Fig. 3).

\section{Scientific knowledge on target species}

We examined 173 papers that included 246 citations for all 24 target species. Most citations were about taxonomy $(n=145)$, representing $59 \%$ of our search, followed by ecology, with $19 \%$ of records $(n=48)$ (Table 2$)$. Although the category "ecology" ranked second in general numbers, less than $17 \%(n=8)$ were specific studies. Citations focusing on distribution $(n=22)$, conservation $(n=19)$ and genetics $(n=12)$ represented $21.5 \%$ of the total literature. Few papers were published in the first four decades ( $n=20$; from 1950 to 1990$)$, with an increasing number from 2000 and the present $(n=135)$ (Fig. 4).

There are few species-specific citations (Fig. 5) and only $26.8 \%$ (66 of 246 citations) contained information on populations of target species (Table 2). Species with the highest number of specific studies are Crossodactylus trachystomus $(n=9)$, followed by Phyllomedusa megacephala $(n=8)$, and Bokermannohyla ibitiguara and Pseudopaludicola mineira, both with five records (Fig. 5). Nine species had only one specific citation, all of them on their taxonomic description (Table 2), and two species had only one record in general and specific literature search, Odontophrynus monachus and I. karst, both of which were recently described (Fig. 5).

\section{DISCUSSION}

\section{Are protected areas enough?}

The great majority of amphibian species that are endemic to Minas Gerais and occur in Cerrado are unsatisfactory or not protected by the current PA network and 


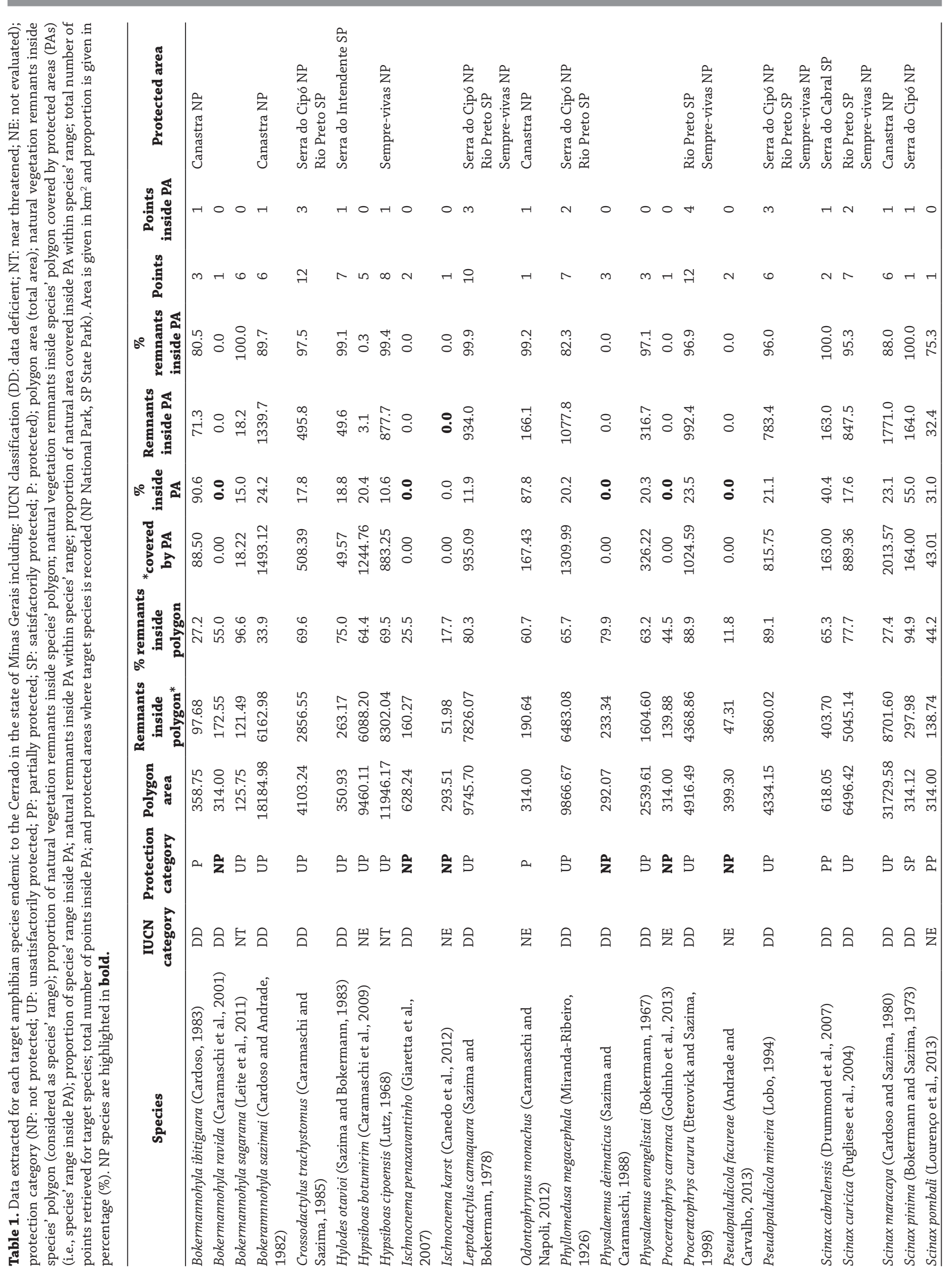


can be considered in a vulnerable situation, with less than $30 \%$ of their range legally protected. This agrees with a recent global analysis showing that the ranges of $>80 \%$ of global DD anurans lie completely outside existing PAs (Nori and Loyola, 2015) and $>50 \%$ of all range restricted amphibian species are not represented in any PA around the world (Nori et al., 2015). Poor PA coverage is also true for other taxonomic groups: most of the world's terrestrial threatened vertebrates (Venter et al., 2014) and 20\% of the Cerrado endemic and threatened species (Klink and Machado, 2005) are not adequately protected. These results highlight the need to incorporate species distribution knowledge when designating PAs and indicate, as noted by Venter et al. (2014), that new PAs must be strategically located to deliver the highest conservation benefits.

Our results reinforce previous recommendations to include DD species in conservation planning, especially
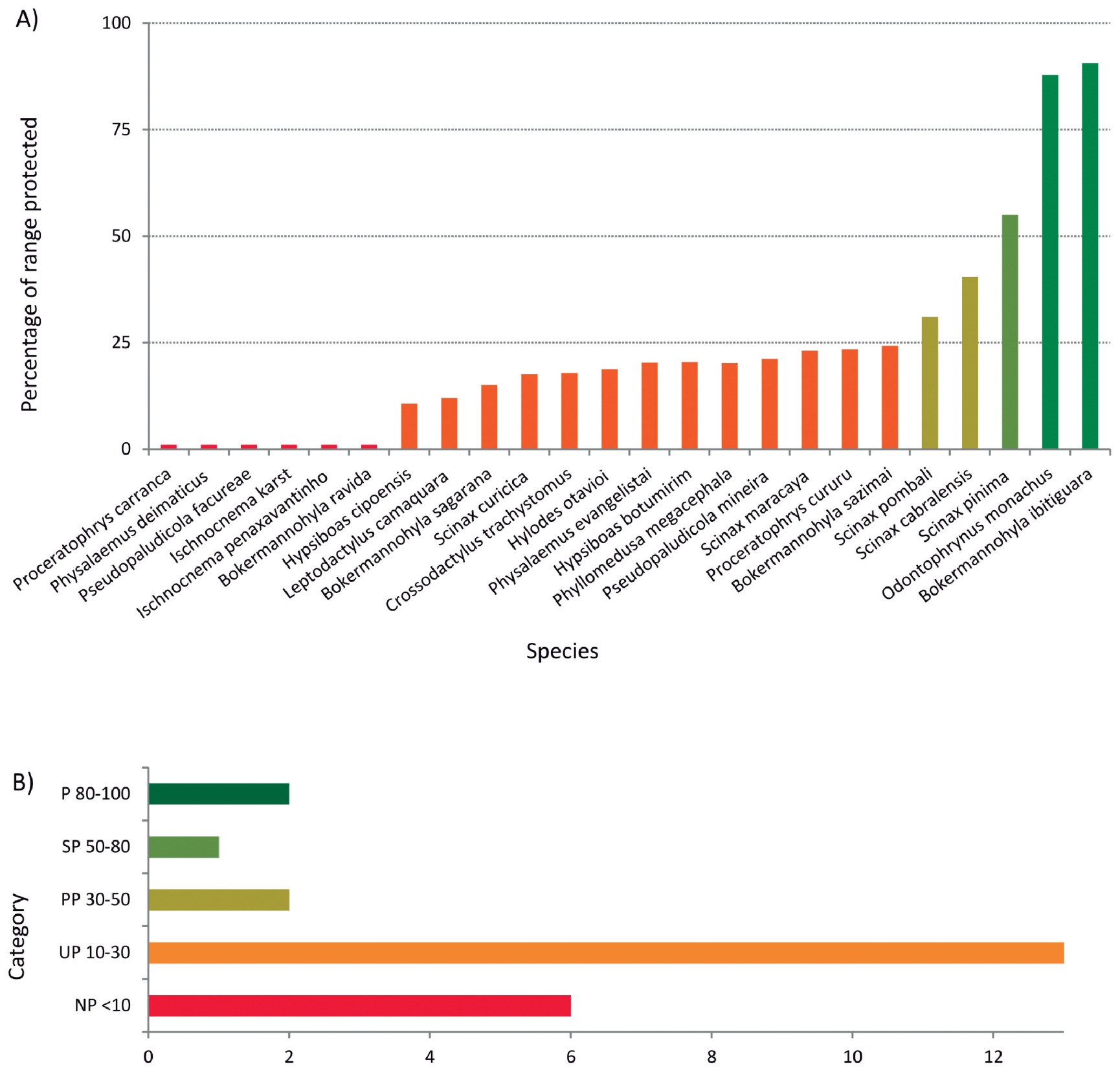

Number of species

Figure 1. (A) Percentage of species ranges inside protected areas and (B) number of species in each protection category according to the percentage of species ranges covered by protected areas for Cerrado amphibian species endemic to Minas Gerais state, southeastern Brazil. NP: not protected, < $10 \%$ of range covered; UP: unsatisfactory protected, $10-30 \%$ of range covered; PP: partially protected, $30-50 \%$ of range covered; SP: satisfactorily protected, 50-80\%; P: protected, > $80 \%$ of range covered. 
with regard to the degree to which they might be threatened in the future (Trindade-Filho et al., 2012; Morais et al., 2013; Nori and Loyola, 2015; Nori et al., 2015). Trindade-Filho et al. (2012) demonstrated that the inclusion of DD species can impact and change the spatial configuration of protected areas network, while Brito (2010) argued that protecting localities with DD species might also protect sites with species unknown to science. Occurrence points for target species might be considered an imperfect representation of their true extent of occurrence, since the distributional range of several DD species is not completely known. While we acknowledge the limitations of using data points to represent the distribution of our targets, we believe our analysis provides the most up-to-date picture of the current scenario for target species in the Cerrado of Minas Gerais.

Considering the high rates of habitat loss and the low percentage of protected habitats in the Cerrado, establishment of new PAs and/or expansion of existing ones is likely to benefit not only the target species within

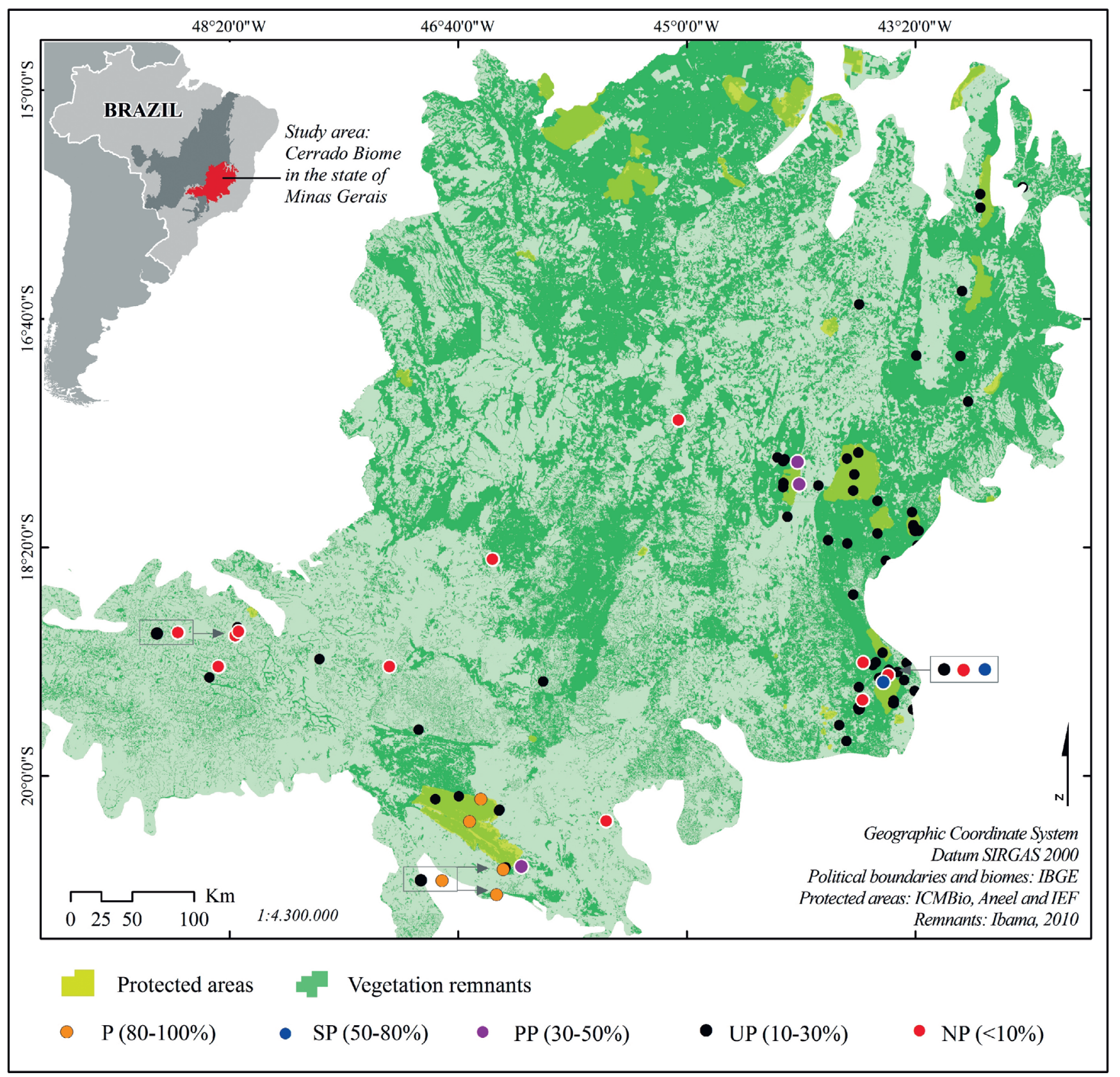

Figure 2. Distribution records of target amphibian species within study area (Cerrado biome in Minas Gerais state, southeastern Brazil), along with protected areas (light green) and vegetation remnants (dark green). Species are labelled according to protection category. NP: not protected, < $10 \%$ of range covered; UP: unsatisfactory protected, $10-30 \%$ of range covered; PP: partially protected, 30-50\% of range covered; SP: satisfactorily protected, 50-80\%; P: protected, $>80 \%$ of range covered. 
this study, but Cerrado biodiversity in general. Although site protection persists as the main conservation recommendation for most globally threatened tetrapods (Boyd et al., 2008), the financial, political, and social costs of establishing strict PAs make this solution feasible only in some cases. Thus, additional strategies must be considered together with PA network expansion, as well as refining the information to where and how conservation efforts should be allocated.

\section{Conservation goals for target species}

Our data clearly show that improvements in the proportion of species ranges that is protected are still required. The decision regarding which species to target with conservation actions is complex and potentially controversial. Evidently, NP species are in a critical situation; however, some NP species are of higher concern than others because they lack continuous natural habitats inside their

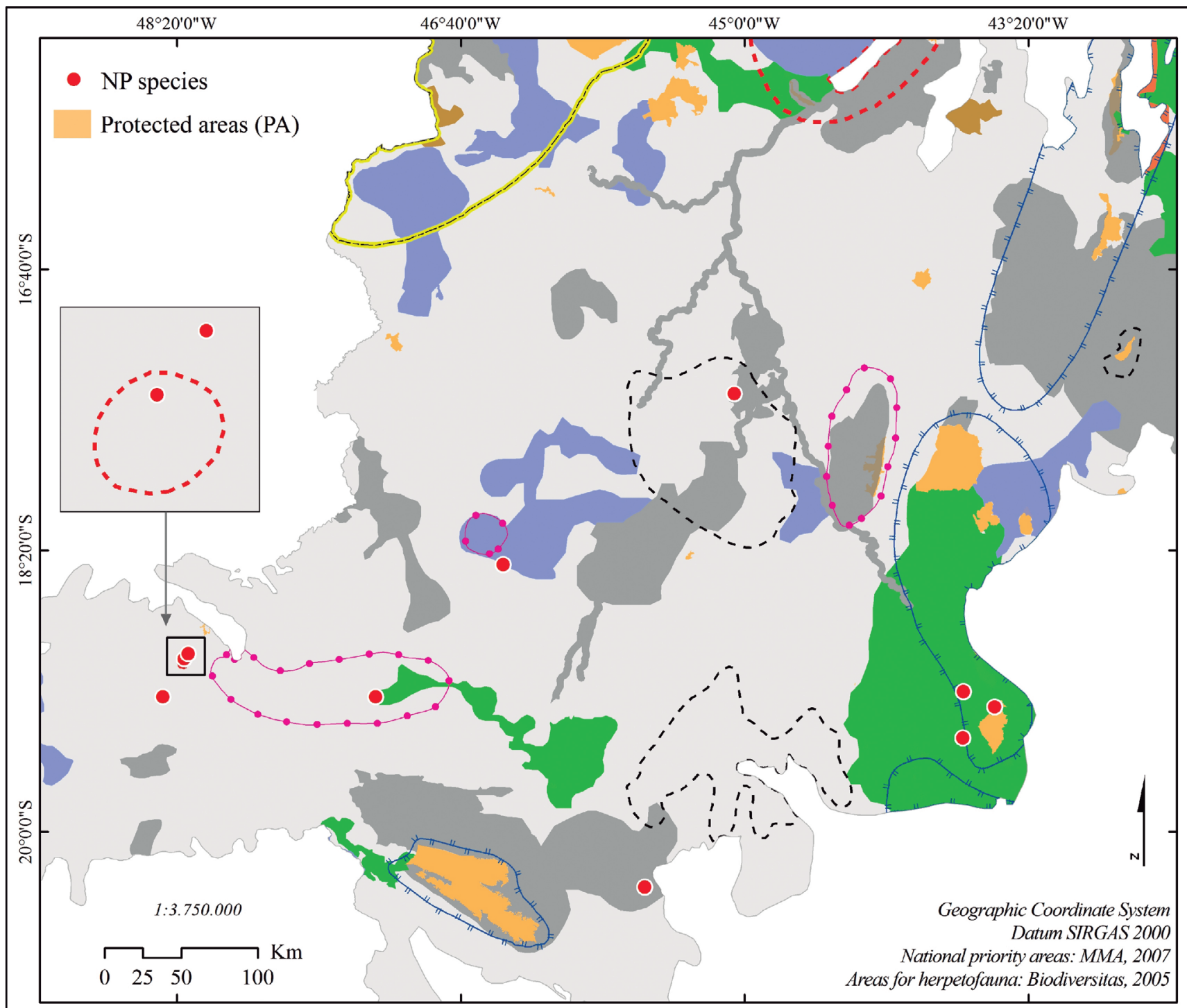

\section{Priority areas for conservation of herpetofauna}

\section{L = I Extreme $=$}

\section{Priority areas for biodiversity conservation}

\section{\begin{tabular}{ll|l|l|l|l|l|l|l} 
Creation of PA & Inventory & Promoting sustainable use & Mecovery
\end{tabular}}

Figure 3. Distribution of Cerrado amphibian species endemic to Minas Gerais state, southeastern Brazil that are not protected (NP) overlapped with protected areas (pale orange), priority areas, and actions recommended for conservation planning. 
Table 2. Summary of scientific papers on target amphibian species endemic to the Cerrado in the state of Minas Gerais. The table reports year of description (Year), total number of citations obtained in the general search within each category and number of specific articles on target species (in parenthesis) for each category, and total number of citations (Total citations) and total number of specific studies (Specific papers) for each species and category.

\begin{tabular}{|c|c|c|c|c|c|c|c|c|c|c|c|c|c|}
\hline \multirow{3}{*}{$\frac{\text { Species }}{\text { Bokermannohyla ibitiguara }}$} & \multirow{3}{*}{$\begin{array}{l}\text { Year } \\
1983\end{array}$} & \multicolumn{10}{|c|}{ Category } & \multirow{3}{*}{$\begin{array}{c}\begin{array}{c}\text { Total } \\
\text { citations }\end{array} \\
22\end{array}$} & \multirow{3}{*}{$\begin{array}{c}\begin{array}{c}\text { Specific } \\
\text { papers }\end{array} \\
5\end{array}$} \\
\hline & & \multicolumn{2}{|c|}{ Conservation } & \multicolumn{2}{|c|}{ Distribution } & \multicolumn{2}{|c|}{ Ecology } & \multicolumn{2}{|c|}{ Genetics } & \multicolumn{2}{|c|}{ Taxonomy } & & \\
\hline & & 0 & (0) & 1 & $(0)$ & 6 & (3) & 2 & (1) & 13 & (1) & & \\
\hline Bokermannohyla ravida & 2001 & 0 & $(0)$ & 0 & (0) & 0 & (0) & 0 & (0) & 5 & (1) & 5 & 1 \\
\hline Bokermannohyla sagarana & 2011 & 0 & $(0)$ & 0 & (0) & 0 & (0) & 0 & (0) & 3 & (1) & 3 & 1 \\
\hline Bokermannohyla sazimai & 1982 & 0 & (0) & 4 & (0) & 0 & (0) & 0 & (0) & 7 & (1) & 11 & 1 \\
\hline Crossodactylus trachystomus & 1985 & 3 & (1) & 1 & (1) & 7 & (1) & 0 & (0) & 7 & (6) & 18 & 9 \\
\hline Hylodes otavioi & 1983 & 2 & $(0)$ & 1 & $(0)$ & 0 & (0) & 0 & (0) & 11 & (1) & 14 & 1 \\
\hline Hypsiboas botumirim & 2009 & 0 & (0) & 0 & $(0)$ & 0 & (0) & 0 & (0) & 4 & (1) & 4 & 1 \\
\hline Hypsiboas cipoensis & 1968 & 0 & (0) & 1 & $(0)$ & 3 & (0) & 0 & (0) & 9 & (2) & 13 & 2 \\
\hline Ischnocnema penaxavantinho & 2007 & 0 & (0) & 1 & (0) & 2 & (1) & 0 & (0) & 3 & (1) & 6 & 2 \\
\hline Ischnocnema karst & 2012 & 0 & (0) & 0 & (0) & 0 & (0) & 0 & (0) & 1 & (1) & 1 & 1 \\
\hline Leptodactylus camaquara & 1978 & 2 & (0) & 1 & (1) & 3 & (0) & 0 & (0) & 7 & (2) & 13 & 3 \\
\hline Odontophrynus monachus & 2012 & 0 & (0) & 0 & $(0)$ & 0 & (0) & 0 & (0) & 1 & (1) & 1 & 1 \\
\hline Phyllomedusa megacephala & 1926 & 3 & (0) & 2 & (1) & 4 & (1) & 3 & (3) & 5 & (3) & 17 & 8 \\
\hline Physalaemus deimaticus & 1988 & 1 & (0) & 2 & $(0)$ & 2 & (0) & 2 & (1) & 9 & $(2)$ & 16 & 3 \\
\hline Physalaemus evangelistai & 1967 & 1 & (0) & 1 & (1) & 3 & (0) & 1 & (0) & 4 & (3) & 10 & 4 \\
\hline Proceratophrys carranca & 2013 & 0 & (0) & 0 & $(0)$ & 2 & (0) & 0 & (0) & 4 & (2) & 6 & 2 \\
\hline Proceratophrys cururu & 1998 & 2 & (0) & 2 & (1) & 6 & (0) & 0 & (0) & 9 & (2) & 19 & 3 \\
\hline Pseudopaludicola facureae & 2013 & 0 & (0) & 0 & $(0)$ & 0 & (0) & 1 & (1) & 5 & (2) & 6 & 3 \\
\hline Pseudopaludicola mineira & 1994 & 2 & (0) & 1 & $(0)$ & 4 & (1) & 2 & (2) & 6 & (2) & 15 & 5 \\
\hline Scinax cabralensis & 2007 & 0 & (0) & 1 & $(0)$ & 0 & (0) & 0 & (0) & 5 & (1) & 6 & 1 \\
\hline Scinax curicica & 2004 & 2 & (0) & 3 & (1) & 5 & (0) & 1 & (1) & 9 & (2) & 20 & 4 \\
\hline Scinax maracaya & 1980 & 0 & (0) & 0 & $(0)$ & 1 & (1) & 0 & (0) & 13 & (1) & 14 & 2 \\
\hline Scinax pinima & 1973 & 1 & (0) & 0 & $(0)$ & 0 & (0) & 0 & (0) & 3 & (2) & 4 & 2 \\
\hline Scinax pombali & 2013 & 0 & (0) & 0 & $(0)$ & 0 & $(0)$ & 0 & $(0)$ & 2 & $(1)$ & 2 & 1 \\
\hline Total & & 19 & 1 & 22 & 6 & 48 & 8 & 12 & 9 & 145 & 42 & 246 & 66 \\
\hline
\end{tabular}

distributions, which means it is likely to be more costly to promote their conservation. This is the case of Pseudopaludicola facureae, Ischnocnema karst and I. penaxavantinho-all NP species with only $11.8,17.7$, and $25.5 \%$ of natural vegetation remnants inside their $\mathrm{MCP}$, respectively. These species occur in southwestern Minas Gerais where national and state priority recommendations are species inventory, creation of PA and corridors, and expansion of existing PA (Serra da Canastra National Park; Drummond et al., 2005; PROBIO/MMA, 2007). Considering the low percentage of available natural habitats for these species, we suggest that habitat restoration and connectivity are more feasible and have better chances of success, together with the creation of private reserves and law enforcement to guarantee riparian habitats protection.

The scenario is different for Physalaemus deimaticus, in southern Espinhaço Range, close to Serra do Cipó National Park, but with zero coverage by PAs and $70 \%$ of native habitat remnants inside its MCP. For this species, expansion of the existing PAs might be feasible; nevertheless, we suggest further investigation on species range, surveying nearby protected areas (Serra do Cipó National Park and Serra do Intendente State Park) to search for new populations. According to Eterovick et al. (2005), the species is known from Serra do Cipó National Park; however, the occurrence points provided show an overlap of less than $0.1 \%$ with PA boundaries.

In addition to NP species, several UP species are also recorded in the Espinhaço Range, where there is still a high percentage of natural vegetation cover outside PAs.

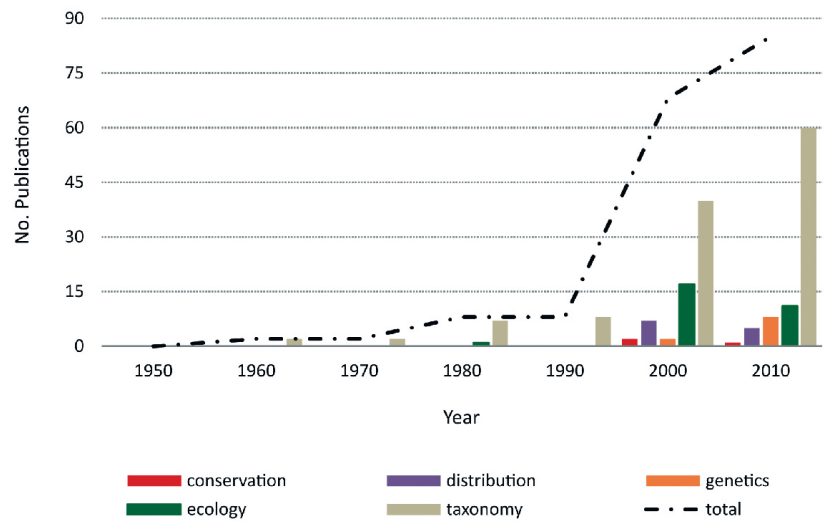

Figure 4. Number of scientific publications 1950-2015 (note: 2010 includes only 2010-present), for each target species of Cerrado amphibians endemic to Minas Gerais state, southeastern Brazil. An evident increase from the late 1990s is shown by the dash-dot line. 
For example, Bokermannohyla sagarana has only $15 \%$ of its range protected by Serra do Cabral State Park, but has $96.6 \%$ of native remnants inside its MCP; or Pseudopaludicola mineira and Proceratophrys cururu that have less than $20 \%$ of their distributions inside PAs and almost $90 \%$ of native habitats within their polygons. Previous recommendations for this region include species inventory, habitat restoration, expansion of existing PAs, and establishment of biodiversity corridors (Drummond et al., 2005; PROBIO/MMA, 2007). Nevertheless, when compared to other regions in the state, the south Espinhaço Range has a considerable number of PAs and, according to Silva et al. (2008), the creation of new PAs in this region is highly costly. Therefore, we believe the most reasonable

\section{Total N papers}

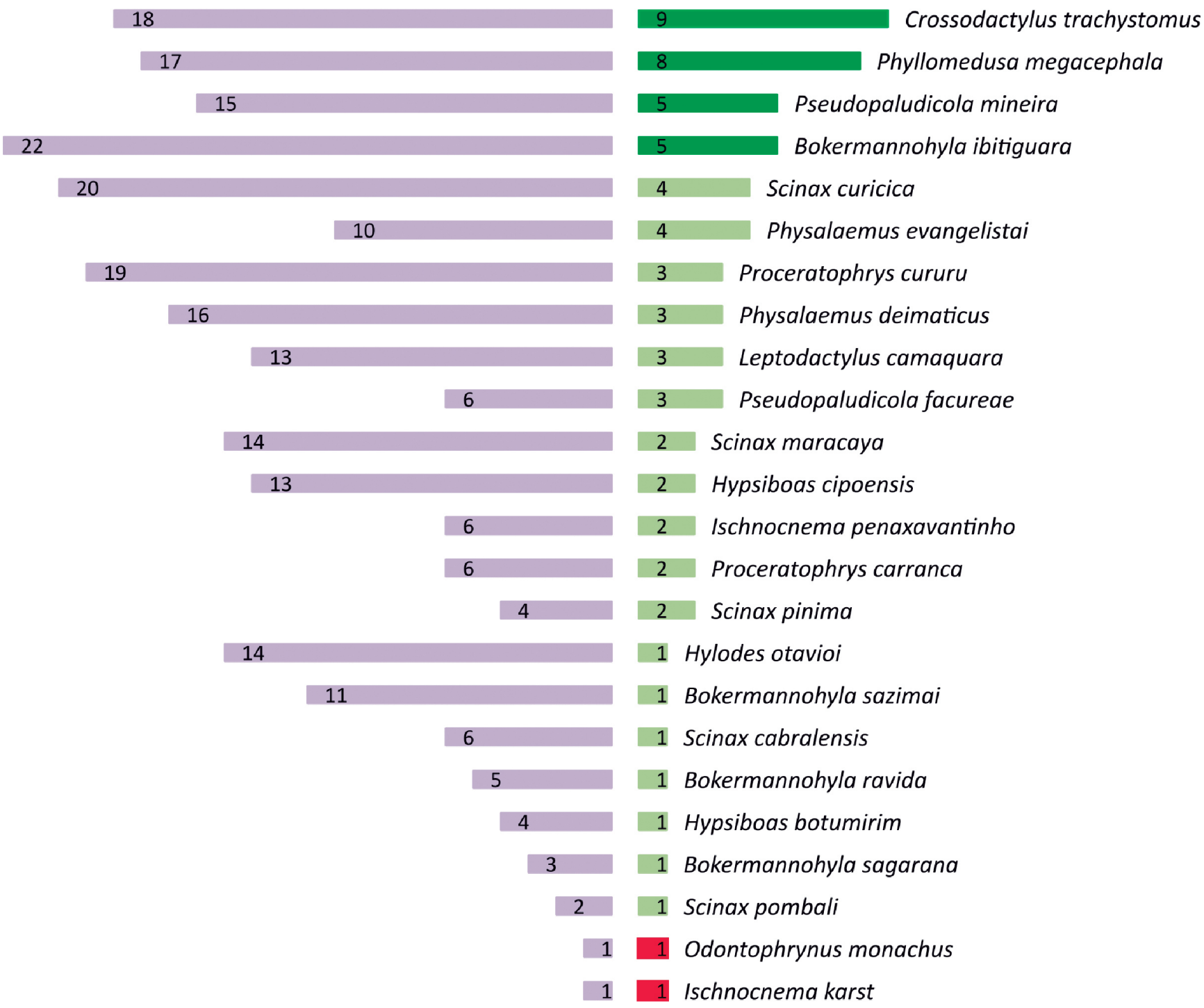

conservation actions would be the establishment of biodiversity corridors connecting existing PAs.

Creation of PAs still stands as probably the best solution for the protection of Proceratophrys carranca and Bokermannohyla ravida, two NP species known only from $44 \%$ and $55 \%$ of natural cover inside their MCPs (respectively). Previous recommendations for this region include habitat restoration and creation of biodiversity corridors (Drummond et al., 2005), but there are few opportunities for connectivity with other PAs within a $100 \mathrm{~km}$ radius for both species. The region is considered a priority area for herpetofauna conservation (Drummond et al., 2005), has relatively low human pressures and high vegetation

Specific papers their type localities in western Minas Gerais and with

Figure 5. Number of publications recorded for each target species (all categories combined) of Cerrado amphibians endemic to Minas Gerais state, southeastern Brazil, showing the proportion of total records (left, pale purple) and specific papers (right, light green). Targets species with more than five publications are highlighted (dark green), as are critical species with only one record provided in total and specific numbers (light red). 
cover, indicating that PA establishment is viable and would result in at least one population of each species to be safeguarded.

\section{Improving scientific knowledge}

Scientific knowledge continues to be insufficient for most DD anuran species endemic to the Cerrado of Minas Gerais and all research categories must be improved to allow the redefinition of each species' status and ultimately inform conservation and management actions. In the state of Minas Gerais, three anurans are critically endangered and seven are vulnerable (all from the Atlantic Rainforest), while 71 are still classified as DD (Nascimento et al., 2009). However, threatened species categories are inconsistent between national and international lists (Morais et al., 2012). Detailed information is needed about the processes affecting the species, without which an accurate assignment of species status is impossible. In general, we still lack sufficient knowledge on most target species. Nevertheless, based on the current literature, we believe some of these species might already have sufficient information to be re-assessed, such as Crossodactylus trachystomus, Phyllomedusa megacephala, Bokermannohyla ibitiguara, Pseudopaludicola mineira and Scinax curicica.

All target species, especially DD species, need further research on their geographical distribution, but some of them must be prioritized, such as recently described species (e.g., Proceratophrys carranca), amphibians with only one or two known occurrence points (e.g., Bokermannohyla ravida) and Physalaemus deimaticus. This would increase known species ranges and help future reviews on effective protection options. For species with 5-10 occurrence points, the modeling method proposed by Teixeira et al. (2015) for Brazilian DD amphibian species in forested habitats might be a useful tool to combine occurrence data, environmental suitability, and connectivity to prioritize sites for field surveys. Additionally, considering the shortage of distribution and status data in the country, we recommend that researchers share their data with conservation planners and practitioners.

Population ecology studies were less represented in our analysis. Controversially, Griffiths and Dos Santos (2012) revealed that the main topic of papers published in conservation journals was population biology, but the most popular taxa were mammals, birds, invertebrates, and plants. However, our analysis focused on amphibians only, a group with a very few specific articles published in main conservation journals (Griffiths and Dos Santos, 2012). Likewise, ecological research focusing on amphibians in Minas Gerais has been developed recently (Nascimento et al., 2009), with an increasing number of professionals in the area. These factors might respond to the expected low number of population-based studies for our target species. While we acknowledge the drawbacks of developing population ecology studies of rare and range-restricted amphibian species, efforts to do so should be increased, since most of the knowledge required to assess conservation status comes from this type of analysis. Ecological studies should focus on target species with better documented occurrences (e.g., Proceratophrys cururu, Leptodactylus camaquara, and Hypsiboas cipoensis in the Espinhaço Range; Bokermannohyla sazimai and Scinax maracaya in Serra da Canastra). Nonetheless, the first step in an ecological approach for species with few data points is to improve knowledge on their distributions.

Since collaboration is required to combine expertise and techniques that can address further conservation problems (Griffiths and Dos Santos, 2012), we also encourage collaborative research on different research subjects, such as genetics and conservation, ecology, and declines. Furthermore, although declines have been a major topic for amphibian conservation worldwide in the last years, research on declines has not been a focus between 2000-2010, at least for the target species in this study. According to Eterovick et al. (2005), in the Cerrado biome a minimum of 20 declining species are lacking ecological or monitoring studies, both of which are urgently needed to provide policy makers with specific recommendations for amphibian conservation.

\section{CONCLUDING REMARKS}

The current network of protected areas is insufficient to safeguard range-restricted and poorly-known anuran species within the Cerrado biome of Minas Gerais state. We have produced a reliable database for a subset of the endemic amphibians of Minas Gerais and provided recommendations on future research and conservation efforts. Our main recommendations concern PA establishment in the western part of the state to safeguard populations of NP species; creation and maintenance of biodiversity corridors between existing PAs and riparian habitat protection to connect UP species populations in the Espinhaço Range; and, finally, habitat restoration in southwestern Minas Gerais to provide additional habitat for NP species within this region. Although scientific knowledge on target species needs much improvement, we provided an update on species range distributions that may be useful in future assessments. Additionally, we have shown that some of the DD species might have enough information to be re-evaluated. More importantly, we expect the results and recommendations provided here to guide state and national agendas, contributing to well-informed conservation actions, improved allocation of resources, better management of PAs, and more reliable species assessments. 


\section{ACKNOWLEDGMENTS}

We are grateful to Instituto Estadual de Florestas de Minas Gerais for financial support (convênio IEF/Biotrópicos 2101010400510). Izabela M. Barata and Guilherme B. Ferreira are supported by $\mathrm{PhD}$ scholarships from CAPES Foundation and $\mathrm{CNPq}$, respectively. We thank Isabela O. Lazarotti, José Paulo Guadanucci and two anonymous reviewers for their comments in earlier drafts of this manuscript. We are thankful to Andrew Buxton and Professor Richard Griffiths for their valuable suggestions and critical review in the final version of this paper.

\section{REFERENCES}

Andrade F.S., Carvalho T.R.. 2013. A new species of Pseudopaludicola Miranda-Ribeiro (Leiuperinae: Leptodactylidae: Anura) from the Cerrado of southeastern Brazil. Zootaxa 3608:389-397. doi:10.11646/zootaxa.3608.5.7

Becker C.G., Fonseca C.R., Haddad C.F.B., Batista R.F., Prado P.I. 2007. Habitat split and the global decline of amphibians. Science 318:1775-1777. doi:0.1126/science.1149374

Beresford A.E., Buchanan G.M., Donald P.F., Butchart S.H.M., Fishpool L.D.C., Rondinini C. 2011. Poor overlap between the distribution of protected areas and globally threatened birds in Africa. Animal Conservation 14:99-107. doi:10.1111/j.1469-1795.2010.00398.x

Bokermann W.C.A. 1967. Trés novas especies de Physalaemus do sudeste brasileiro (Amphibia, Leptodactylidae). Revista Brasileira de Biologia 27:135-143.

Bokermann W.C.A., Sazima I. 1973. Anfíbios da Serra do Cipó, Minas Gerais, Brasil. II: Duas espécies novas de Hyla (Anura, Hylidae). Revista Brasileira de Biologia 33:521-528.

Boyd C., Brooks T.M., Butchart S.H., Edgar G.J., da Fonseca G.A., Hawkins F., ... Van Dijk P.P. 2008. Spatial scale and the conservation of threatened species. Conservation Letter 1:37-43. doi: 10.1111/j.1755-263X.2008.00002.x

Brito D. 2010. Overcoming the Linnean shortfall: data deficiency and biological survey priorities. Basic and Applied Ecology 11:709-713. doi:10.1016/j.baae.2010.09.007

Canedo C., Targino M., Leite F.S.F., Haddad C.F.B. 2012. A new species of Ischnocnema (Anura) from the São Francisco Basin karst region, Brazil. Herpetologica 68:393-400. doi:10.1655/ HERPETOLOGICA-D-11-00065.1

Caramaschi U., Napoli M.F. 2012. Taxonomic revision of the Odontophrynus cultripes species group, with description of a new related species (Anura, Cycloramphidae). Zootaxa 3155:1-20.

Caramaschi U., Sazima I. 1985. Uma nova espécie de Crossodactylus da Serra do Cipó, Minas Gerais, Brasil (Amphibia, Leptodactylidae). Revista Brasileira de Zoologia 3:43-49. doi:10.1590/ S0101-81751985000100005

Caramaschi U., Napoli M.F., Bernardes A.T. 2001. Nova espécie do grupo do Hyla circumdata (Cope, 1870) do estado de Minas Gerais, Brasil (Amphibia, Anura, Hylidae). Boletim do Museu Nacional 457:1-11.

Caramaschi U., Cruz C.A.G., Nascimento L.B. 2009. A new species of Hypsiboas of the H. polytaenius clade from southeastern Brazil (Anura: Hylidae). South American Journal of Herpetology 4:210-216. doi:10.2994/057.004.0302

Cardoso A.J. 1983. Descrição e biologia de uma nova espécie de Hyla Laurenti, 1768 (Amphibia, Anura, Hylidae). Iheringia. Série Zoologia 62:37-45.
Cardoso A.J., Andrade G.V. 1982. Nova espécie de Hyla do Parque Naconal Serra da Canastra (Anura, Hylidae). Revista Brasileira de Biologia 42:589-593.

Cardoso A.J., Sazima I. 1980. Nova espécie de Hyla do sudeste brasileiro (Amphibia, Anura, Hylidae). Revista Brasileira de Biologia 40:75-79.

CBD Convention on Biological Diversity. 2015. Aichi Biodiversity Targets. Accessible at https://www.cbd.int/sp/targets/default. shtml

Diniz-Filho J.A.F., Bini L.M., Pinto M.P., Rangel T.F.L.V.B., Carvalho P., Bastos R.P. 2006. Anuran species richness, complementarity and conservation conflicts in Brazilian Cerrado. Acta Oecologica International Journal of Ecology 29:9-15. doi:10.1016/j. actao.2005.07.004

Diniz-Filho J.A.F., Bini L.M., Pinto M.P., Rangel T., Carvalho P., Vieira S.L., Bastos R.P. 2007. Conservation biogeography of anurans in Brazilian Cerrado. Biodiversity and Conservation 16:9971008. doi:10.1007/s10531-006-9010-4

Dudley N. 2008. Guidelines for applying protected area management categories. IUCN, Gland.

Drummond G.M., Martins C.S., Machado A.B.M., Sebaio F.A., Antonini, Y. 2005. Biodiversidade em Minas Gerais: um atlas para a sua conservação. Fundação Biodiversitas, Belo Horizonte.

Drummond L.O., Baêta D., Pires M.R.S. 2007. A new species of Scinax (Anura, Hylidae) of the S. ruber clade from Minas Gerais, Brazil. Zootaxa 1612:45-63.

Eterovick P.C., Sazima I. 1998. New species of Proceratophrys (Anura: Leptodactylidae) from southeastern Brazil. Copeia 1998:159-164. doi:10.2307/1447712

Eterovick P.C., Carnaval A.C.O.Q., Borges-Nojosa D.M., Silvano D.L., Degalla M.V., Sazima I. 2005. Amphibian declines in Brazil: an overview. Biotropica 37:166-179. doi:10.1111/j.1744-7429.2005.00024.x

Frost D.R. 2014. Amphibian Species of the World: an Online Reference. Version 5.4. Accessible at http://research.amnh.org/herpetology/ amphibia/index.html

Giaretta A.A., Toffoli D., Oliveira L.E. 2007. A new species of Ischnocnema (Anura: Eleutherodactylinae) from open areas of the Cerrado Biome in southeastern Brazil. Zootaxa 1666:53-51.

Godinho L.B., Moura M.R., Lacerda J.V.A., Feio R.N. 2013. A new species of Proceratophrys (Anura: Odontophrynidae) from the middle São Francisco River, southeastern Brazil. Salamandra 49:63-73.

Griffiths R.A., Dos Santos L. 2012. Trends in conservation biology: progress or procrastination in a new millennium? Biological Conservation 153:153-158. doi:10.1016/j.biocon.2012.05.011

Griffiths R.A., Sewell D., McCrea R.S. 2010. Dynamics of a declining amphibian metapopulation: Survival, dispersal and the impact of climate. Biological Conservation 143:485-491. doi:10.1016/j. biocon.2009.11.017

IBGE Instituto Brasileiro de Geografia e Estatística. 2014. Mapa dos biomas brasileiros. Accessible at http://ibge.gov.br

IUCN Standards and Petitions Subcommittee. 2013. Guidelines for using the IUCN Red List categories and criteria. Version 10.1. Accessible at www.iucnredlist.org/documents/RedListGuidelines.pdf

IUCN International Union for Conservation of Nature. 2014. IUCN Red List of threatened species. Version 2011.1. Accessible at http://iucnredlist.org

Juffe-Bignoli D., Burgess N.D., Bingham H., Belle E.M.S., de Lima M.G., Deguignet M., ... Kingston N. 2014. Protected planet report 2014. UNEP-WCMC, Cambridge.

Kiesecker J.M. 2002. Synergism between trematode infection and pesticide exposure: A link to amphibian limb deformities in nature? Proceedings of the National Academy of Science 99:9900-9904. doi:10.1073pnas.152098899

Klink C.A., Machado R.B. 2005. A conservação do Cerrado brasileiro. Megadiversidade 1:147-155.

Leite F.S.F., Pezzuti T.L., Drummond L.o. 2011. A new species of Bokermannohyla from the Espinhaço Range, state of Minas 
Gerais, southeastern Brazil. Herpetologica 67:440-448. doi:10.1655/ HERPETOLOGICA-D-11-00017.1

Lips K.R., Diffendorfer J., Mendelson J.R. III, Sears M.W. 2008. Riding the wave: reconciling the roles of disease and climate change in amphibian declines. PLoS Biology 6:e72. doi:10.1371/journal. pbio. 0060072

Lobo F. 1994. Descripción de una nueva especie de Pseudopaludicola (Anura: Leptodactylidae), redescripción de P. falcipes (Hensel, 1867) y P. saltica (Cope, 1887). Cuadernos de Herpetología 8:177-199.

Lourenço A.C.C., Carvalho A.L.G., Baêta D., Pezzuti T.L., Leite F.S.F.. 2013. A new species of the Scinax catharinae group (Anura, Hylidae) from Serra da Canastra, southwestern state of Minas Gerais, Brazil. Zootaxa 3613:573-588. doi:10.11646/zootaxa.3889.2.5

Lutz B. 1968. Geographic variation in Brazilian species of Hyla. Pearce-Sellards Series 12:1-13.

Mace G.M., Collar N.J., Gaston K.J., Hilton-Taylor C., Akçakaya H.R., Leader-Williams N., ... Stuart S.N. 2008. Quantification of extinction risk: IUCN's system for classifying threatened species. Conservation Biology 22:1424-1442. doi:10.1111/j.1523-1739.2008.01044.x

Miranda-Ribeiro A. 1926. Notas para servirem ao estudo dos gymnobatrachios (Anura) Brasileiros. Arquivos do Museu Nacional 27:1-227.

MMA/ICMBio. 2014. Cadastro nacional de unidades de conservação. Accessible at www.mma.gov.br

Morais A.R., Braga R.T., Bastos R.P., Brito D. 2012. A comparative analysis of global, national, and state red lists for threatened amphibians in Brazil. Biodiversity and Conservation 21:2633-2640. doi:10.1007/s10531-012-0322-2

Morais A.R., Siqueira M.N., Lemes P., Maciel N.M., De Marco P., Brito D. 2013. Unraveling the conservation status of Data Deficient species. Biological Conservation 166:98-102. doi:10.1016/j. biocon.2013.06.010

Nascimento L.B., Leite F.S.F., Eterovick P.C., Feio R.N. 2009. Anfíbios. Pp. 221-248, in Drummond G.M., Martins C.S., Greco M.B., Vieira F. (Org.), Diagnóstico do Conhecimento sobre a Biodiversidade no Estado de Minas Gerais - Subsídio ao Programa BIOTA MINAS. Fundação Biodiversitas, Belo Horizonte.

Nori J., Loyola R. 2015. On the worrying fate of Data Deficient amphibians. PLoS ONE 10:e0125055. doi:10.1371/journal.pone.0125055

Nori J., Lemes P., Urbina-Cardona N., Baldo D., Lescano J., Loyola R. 2015. Amphibian conservation, land-use changes and protected areas: A global overview. Biological Conservation 191:367-374. doi:10.1016/j.biocon.2015.07.028

Pereira H.M., Navarro L.M., Martins I.S. 2012. Global biodiversity change: the bad, the good, and the unknown. Annual Review of Environment and Resources 37:25-50. doi:10.1146/ annurev-environ-042911-093511

Pugliese A., Pombal Jr. J.P., Sazima I. 2004. A new species of Scinax (Anura: Hylidae) from rocky montane fields of the Serra do Cipo, southeastern Brazil. Zootaxa 688:1-5.

IBAMA/PMDBBS. 2011. Projeto de Monitoramento do Desmatamento dos Biomas Brasileiros por Satélite. Accessible at http://siscom. ibama.gov.br/monitora_biomas/index.htm

Pounds J.A., Bustamante M.R., Coloma L.A., Consuerga J.A., Fogden M.P.L., Foster P.N., ... Young B.E. 2006. Amphibian extinctions from epidemic disease driven by global warming. Nature 439:161-167. doi:10.1038/nature04246

PROBIO/MMA Projeto de Conservação e Utilização Sustentável da Diversidade Biológica Brasileira/Ministério do Meio
Ambiente. 2007. Mapas de Cobertura Vegetal dos Biomas Brasileiros. Accessible at http://mapas.mma.gov.br/mapas/aplic/probio/ datadownload.htm

Rodrigues S.L.A., Andelman S.J., Bakarr M.I., Boitanis L., Brooks T.M., Cowling R.M., ... Yan X. 2004. Effectiveness of the global protected area network in representing species diversity. Nature 428:640-643. doi:10.1038/nature02422

Sazima I., Bokermann W.C.A. 1978. Cinco novas espécies de Leptodactylus do centro e sudeste Brasileiro (Amphibia, Anura, Leptodactylidae). Revista Brasileira de Biologia 38:899-912.

Sazima I., Bokermann W.C.A. 1983 "1982". Anfíbios da Serra do Cipó, Minas Gerais, Brasil. 5: Hylodes otavioi sp. n. (Anura, Leptodactylidae). Revista Brasileira de Biologia 42:767-771.

Sazima I., Caramaschi U. 1988 “1986”. Descricao de Physalaemus deimaticus sp. n., e observações dobre comportamento deimatico em P. nattereri (Steindn.) Anura. Revista de Biologia 13:91-101.

Shoo L.P., Olson D.H., McMenamin S.K., Murray K.A., Sluys M.V., Donnelly M.A., ... Hero J.M. 2011. Engineering a future for amphibians under climate change. Journal of Applied Ecology 48:487492. doi:10.1111/j.1365-2664.2010.01942.x

Silva J.A., Machado R.B., Azevedo A.A., Drummond G.M., Fonseca R.L., Goulart M.F., ... Ramos Neto M.B. 2008. Identificação de áreas insubstituíveis para conservação da Cadeia do Espinhaço, estados de Minas Gerais e Bahia, Brasil. Megadiversidade 4:272-309.

SNUC Sistema Nacional de Unidades de Conservação. 2000. Sistema Nacional de Unidades de Conservação. Lei Federal No 9.985, de 18 de julho de 2000. Brasil.

Sritharan S., Burgess N.D. 2012. Protected area gap analysis of important bird areas in Tanzania. African Journal of Ecology 50:66-76. doi:10.1111/j.1365-2028.2011.01295.x

Stuart S.N., Chanson J.S., Cox N.A., Young B.E., Rodrigues A.S.L., Fischman D.L., Waller, R.W. 2004. Status and trends of amphibian declines and extinctions worldwide. Science 306:1783-1786. doi:10.1126/science. 1103538

Teixeira T.S., Weber M.M., Dias D., Lorini M.L., Esbérard C.E.L., Novaes R.L., ... Vale M.M. 2014. Combining environmental suitability and habitat connectivity to map rare or Data Deficient species in the tropics. Journal for Nature Conservation 22:384-390. doi:10.1016/j.jnc.2014.04.001

Trindade-Filho J., de Carvalho R.A., Brito D., Loyola R.D. 2012 How does the inclusion of Data Deficient species change conservation priorities for amphibians in the Atlantic Forest? Biodiversity and Conservation 21:2709-2718. doi:10.1007/s10531-012-0326-y

Valdujo P.H., Silvano D.L., Colli G., Martins M. 2012. Anuran species composition and distribution patterns in Brazilian Cerrado, a Neotropical hotspot. South American Journal of Herpetology 7:6378. doi:10.2994/057.007.0209

Venter O., Fuller R.A., Segan D.B., Carwardine J., Brooks T., Butchart S.H., ... Possingham H.P. 2014. Targeting global protected area expansion for imperiled biodiversity. PLoS Biology 12:e1001891. doi:10.1371/journal.pbio.1001891

Watson J.E.M., Dudley N., Segan D.B., Hockings M. 2014. The performance and potential of protected areas. Nature 515:67-73. doi:10.1038/nature13947

Young B., Lips K.R., Reaser J.K., Ibáñez R., Salas A.W., Cedeño J.R., ... Romo D. 2001. Population declines and priorities for amphibian conservation in Latin America. Conservation Biology 15:1213-1223. doi:10.1111/j.1523-1739.2001.00218.x 